\title{
Board of Directors' Characteristics and Conditional Accounting Conservatism: Spanish Evidence $\equiv$
}

\author{
JUAN MANUEL GARCÍA LARA*, BEATRIZ GARCÍA OSMA** \\ AND FERNANDO PENALVA $\dagger$
}

*Universidad Carlos III de Madrid, Spain, ** Universidad Autónoma de Madrid, Spain and ${ }^{\dagger} I E S E$ Business School, Universidad de Navarra, Spain

\begin{abstract}
Using a sample of Spanish listed firms for the period 19972002 we find that firms where the CEO has a low influence over the functioning of the board of directors show a greater degree of accounting conservatism. We measure the influence of the CEO over the board of directors using two aggregate indexes combining six (eight) characteristics of the functioning of the board of directors and its monitoring committees: board size, proportion of non executive directors, proportion of independent directors, whether the chairman of the board is an executive director, the number of board meetings, and the existence of an audit committee, a nomination/remuneration committee and an executive committee. We define conservatism as the asymmetric recognition speed of good and bad news in earnings, and we measure it following Basu (Journal of Accounting and Economics, 24, pp. 3 37, 1997) and Ball and Shivakumar (Journal of Accounting and Economics, 39, pp. 83 128, 2005). Our results are robust to alternative specifications and specific controls for investment opportunities and for the endogenous nature of corporate governance and earnings quality. Overall, our evidence shows that firms with strong boards use conservative accounting numbers as a governance tool, even in an institutional setting with low litigation risk such as Spain.
\end{abstract}

\section{Introduction}

Basu (1997) defines accounting conservatism as the asymmetric recognition speed of good and bad news in earnings. Conservatism is commonly defined by accounting frameworks as a prudent reaction to uncertainty destined to

Correspondence Address: Juan Manuel García Lara, Department of Business Administration, Univer sidad Carlos III de Madrid, C/Madrid 126, 28903 Getafe, Madrid, Spain. E mail: juanmanuel.garcia @uc3m.es 
protect the rights and claims of debt-holders and shareholders that imposes a higher standard of verification to recognize good news than bad news in earnings, generating earnings that reflect bad news in a timelier fashion. Basu predicts and finds that earnings and prices tend to reflect bad news simultaneously, whilst prices reflect good news faster than accounting earnings. This prediction is at the root of Basu's conservatism measure: the asymmetric timeliness of earnings; commonly denoted conditional conservatism, earnings conservatism or ex post conservatism. ${ }^{1}$ Recent literature identifies another type of conservatism: unconditional, balance-sheet or ex ante conservatism, which is news independent and generates a persistent understatement of shareholders equity (Feltham and Ohlson, 1995; Beaver and Ryan, 2005).

Conservatism has been a salient characteristic of accounting information for centuries, and recent research into this area has documented a significant increase in conservatism in the last few decades (Givoly and Hayn, 2000). Several explanations are presented to justify the existence of conservatism, and all of them coincide in highlighting that conservatism benefits the users of financial information. These explanations may be grouped into four categories: (1) contracting motivations; (2) litigation risk; (3) tax optimization; and (4) asymmetries in the loss functions of regulators. The existing empirical evidence provides support for the contractual and litigation explanations, although taxation and regulation also contribute to the existence of conservatism (Watts, 2003b).

Watts (2003a) explains that, from the point of view of contracting and litigation risk, conservatism originates from the existence of (1) information asymmetries; (2) asymmetries in compensation contracts; (3) limited liability; and (4) the fact that the parties to the firm have different time-horizons. Conservative accounting numbers can be used in contracts among the different parties to the firm to reduce moral hazard problems created by the aforementioned asymmetries. Contracts based on conservative (prudent) numbers reduce the probability of managerial expropriation of shareholders' resources or of excessive distribution of resources to the shareholders at the expense of debt-holders. The asymmetric verification requirements of good and bad news that conservatism imposes contributes to limit managerial opportunism, thereby increasing firm value, which benefits all the economic agents.

Corporate governance mechanisms likely play a significant role in the implementation of accounting conservatism. Corporate governance encompasses all the provisions and mechanisms that guarantee that the assets of the firm are managed efficiently and in the interests of the providers of finance, mitigating the inappropriate expropriation of resources by managers or any other party to the firm. At the centre of this decision-making and control system is the board of directors, which plays a fundamental role in the government of large companies. The implementation of mechanisms that facilitate and improve the monitoring and control exerted by the board over senior managers is expected to result in increased managerial evaluation and control, reductions in litigation risk, enhanced auditor independence and, particularly, in a demand for timelier 
accounting information. The acceleration in the recognition of bad news provides the board of directors with early warning signals to investigate the origin of bad news. These positive outcomes that derived from the strengthening of the functioning of the board of directors coincide with those associated to accounting conservatism, giving rise to the main prediction of this study.

We predict that firms with stronger corporate governance mechanisms in place (stronger boards) will present more conditionally conservative accounting numbers, as defined by Basu (1997) and by Ball and Shivakumar (2005). We focus on conditional conservatism as it plays a clear role in the contracting and monitoring functions of corporate governance. However, it is difficult to see how contracting is affected by conservatism in the form of an unconditional accounting bias of known magnitude. Rational agents would simply invert the bias. Moreover, if the bias is unknown, it can only reduce contracting efficiency (Ball and Shivakumar, 2005).

Thus, it is expected that the sensitivity of earnings to bad news will be greater in firms where the board of directors has greater control over the chief executive officer (CEO) than in firms with weaker boards. Governance is a complex construct with multiple dimensions. Our study focuses on one of these dimensions: the board of directors and its delegate committees. Therefore, when we employ the expression corporate governance, we do it in this restrictive sense. To measure board of directors' quality we develop two aggregate indexes that take into account several characteristics of the functioning of the board and its committees.

To test our prediction, we use a sample of 69 Spanish quoted companies for the period 1997 2002. The results indicate that firms where the CEO has low influence over the functioning of the board of directors show a greater degree of accounting conservatism than firms where the CEO has a high influence over the board. Thus, the earnings of strong corporate governance firms reflect bad news in a timelier (faster) fashion than the earnings of firms where the CEO has a large influence over the board. In addition, the results show that good news is incorporated into earnings with a greater lag in firms with stronger boards.

The first study on the links between corporate governance and accounting conservatism is the UK-based work of Beekes et al. (2004), who show that firms with a higher percentage of non-executive directors tend to recognize bad news in a timelier fashion as measured by Basu's method. These results are confirmed by Ahmed and Duellman (2007) who, using three different measures of conservatism, document for a US sample that (i) the percentage of inside directors is negatively related to conservatism, and (ii) the percentage of outside directors' shareholdings is positively related to conservatism. In line with this evidence, García Lara et al. (2009) also find a positive association between accounting conservatism and corporate governance for US firms, and Lobo and Zhou (2006) present evidence of an increase in conservatism as a result of the provisions of the Sarbanes Oxley Act to strengthen corporate governance. 
Our study differs from those of Beekes et al. (2004) and Ahmed and Duellman (2007) along several dimensions. First, we incorporate a more extensive measure of governance, building an aggregate index that takes into account not only directors' denominations, but seven additional characteristics of the functioning of the board of directors: board size, proportion of non-executive directors, proportion of independent directors, whether the chairman of the board is an executive director, the number of board meetings, and the existence of an audit committee, a nomination/remuneration committee and an executive committee. ${ }^{2}$ By using this aggregate index, we can account for the existence of interactions between the different mechanisms, and the fact that the performance of each of these mechanisms may affect the effectiveness of the rest. The use of an aggregate index is particularly justified in the case of Spain, since recent literature shows that independent boards are inefficient in securing earnings quality unless independent directors are supported by other governance mechanisms, such as an independent nomination and remuneration committee (García Osma and Gill de Albornoz, 2007). Second, our analysis takes into account firm growth opportunities when studying the differences in the asymmetric recognition of good and bad news across governance structures. This is a necessary control, because otherwise any observed differences between governance structures could be driven by changes in growth opportunities (and the effects of the understatement of assets) instead of by changes in conservatism (Roychowdhury and Watts, 2007). Third, we acknowledge the endogenous nature of governance choice and control for a set of firm characteristics that may affect this choice. Fourth, we use an alternative measure to the Basu (1997) conservatism model: the Ball and Shivakumar (2005) measure, which is entirely accountingbased. The reason for using an alternative measure of conditional conservatism is the recent evidence in Dietrich et al. (2007), who show that the Basu approach may produce biased results and recommend the use of alternative methods to validate the results. Finally, we analyse a sample of Spanish firms; to the best of our knowledge, this is the first piece of empirical evidence that investigates the role of conservatism in governance in a civil-law setting, such as Spain. Prior research highlights the differences in the role played by conservative accounting between common-law and civil-law accounting regimes.

The remainder of the paper is organized as follows. Section 2 describes the association between corporate governance and accounting conservatism, and the role of governance and conservative accounting numbers in a civil-law setting such as Spain. Section 3 details the research method, describing the governance and conservatism measures used in our empirical tests. The sample selection procedure is described in Section 4, which also contains variable descriptive statistics. The results, including the impact of board of directors' characteristics on conservatism measures are presented in Section 5, where the main sensitivity checks are also explained. Finally, Section 6 concludes. 


\section{Corporate Governance and Conditional Conservatism}

The design of firm governance, through the creation of mechanisms, instruments and provisions that strengthen and support the monitoring role of the board of directors, is aimed at guaranteeing that investors obtain a return for their investment (Shleifer and Vishny, 1997). Managerial monitoring is exerted both via natural mechanisms, such as capital market pressures, firm ownership structure or leverage; and institutional mechanisms, such as auditors, boards of directors and monitoring committees. ${ }^{3}$ In this section, we first describe the central role played by corporate boards within this governance control system, paying particular attention to current Spanish governance practices and guidance, and then, we present our predictions on the association between stronger boards of directors and conditional conservatism.

\subsection{Corporate Governance Structure: The Monitoring Role of the Board of Directors}

Previous research provides mounting evidence that the functioning and characteristics of the board of directors is associated not only to firm performance, but also to the distribution of power within the firm, and how this distribution affects the distribution of rents. For instance, the evidence in Core et al. (1999) shows that board characteristics associated to weak corporate governance for example, when the CEO is also the chairman of the board, when board members are nominated by the CEO, or there is a high presence of very old or busy directors are correlated with higher CEO remuneration, after controlling for other economic factors that could justify higher CEO compensation. Core et al. (1999) find that their prediction of excess CEO compensation, based on firm governance structure, has a negative correlation with future returns in one, three and five year time-horizons.

There are several arguments that provide a theoretical foundation for these results. The main one is based on agency theory: deficient governance structures generate an increase in agency costs. Agency costs appear because of the lack of alignment between the interests and incentives of the different agents and parties to the firm, as each agent attempts to maximize his own utility instead of firm value. These agency costs translate, among other things, into lower operational performance, higher rents for managers, excess resource distribution to shareholders at the expense of debt-holders, and are consistent with the existence of inefficient contracts among the parties. The board of directors plays a central role in monitoring and controlling the behaviour of senior managers, protecting the interests of the different parties to the firm and ameliorating these agency conflicts and improving contracting efficiency (Fama, 1980; Fama and Jensen, 1983).

\subsubsection{Corporate boards in Spain}

Awareness of the importance of firm governance has existed for many decades; however, corporate governance regulation is a relatively recent development in 
Spain. The first Spanish governance code is the Olivencia Report (1998), which focuses on the role of the board of directors in constraining aggressive accounting practices that reduce the transparency and reliability of financial statements. The Olivencia Report, of voluntary adoption, consists of 23 good governance recommendations, out of which, 19 directly relate to the composition, size, functioning and characteristics of the board of directors and its monitoring committees. This highlights the central role assigned to the board, and particularly, to independent directors. Inside directors are expected to align themselves closely with the CEO. Hence, it is independent directors that shoulder the task of monitoring management. As described in the Olivencia Report, there are three types of directors in Spanish boards: (i) inside directors that hold managerial positions; (ii) institutional directors that represent the interests of large shareholders and institutional investors; and (iii) outside directors, who are experts that hold no stock in the company. The Report considers both outside and institutional directors as independent, and assigns them the role of monitoring and evaluating management, with the ultimate goal of improving the quality of financial statements.

Thus, these governance recommendations align themselves closely to early governance codes such as the UK's Cadbury Report (1992). However, Spain is a civil-law regime. Corporate governance demands and the underlying institutional setting significantly differ between common and civil-law regimes. In particular, the quality of enforcement, the level of investor protection, firm ownership structures and litigation risk for auditors and directors are expected to be dissimilar (see, e.g. LaPorta et al., 1998, 1999), creating different governance needs and incentives, which raise concerns that these governance measures may not be equality efficient in civil-law settings.

As pointed out by Beekes et al. (2004), for boards of directors to be efficient monitors two conditions must be met: (i) independent directors must possess sufficient incentives to monitor; and (ii) they must understand the financial reporting system. While it is reasonable to assume that directors have a grasp on the financial reporting process, due to the lack of an economic, social and legal tradition of Spanish directors (Recalde, 2003), there may be doubts that the first condition is met, particularly in the case of outside directors as institutional directors assume the monitoring role of institutional investors identified by Shleifer and Vishny (1986). Additionally, in civil-law regimes the demand for conditional conservative measures is lower than in common-law countries given the low litigation risk and high unconditional conservatism (Ball et al., 2000; Giner and Rees, 2001; García Lara and Mora, 2004; García Lara et al., 2005; Bushman and Piotroski, 2006; Gassen et al., 2006).

In recent years, there have been several changes to Spanish governance regulatory framework that cast additional doubts over the efficiency of the initial recommendations. The Aldama Report (2003) denounced a poor implementation of the Olivencia governance recommendations and a new law was passed in Spain in 2002 (law 44/2002), whereby, for example, quoted companies are now obliged to have an audit committee composed of a majority of independent 
directors. From 2008 onwards, a new good governance code will be implemented: the Conthe Report (2006) that combines the recommendations of the Olivencia and the Aldama reports, and has met significant opposition from Spanish quoted companies, due to its more restricted definition of who may serve as an independent director.

Thus, the positive association between governance and conservatism found by previous research in this area need not hold in a civil-law setting such as Spain.

\subsection{The Links between Governance Monitoring and Accounting Conservatism}

Accounting conservatism provides significant benefits for the users of financial information. The use of conservative accounting numbers in contracts among the different parties to the firm reduces information asymmetries and moral hazard problems derived from agency conflicts (Watts, 2003b). Contracts written using prudent numbers reduce the probability of managerial expropriation of firm resources or excess distribution of these resources. Therefore, it is expected that timely incorporation of economic losses (bad news) into earnings will reduce the opportunities for managerial opportunistic behaviour, facilitating managerial monitoring, as well as the monitoring of firm contracts, such as debt contracts. Due to these beneficial effects, accounting conservatism is commonly considered as an indicator of earnings quality or a desirable property of accounting earnings (Watts, 2003b; Francis et al., 2004; Ball and Shivakumar, 2005).

Nevertheless, some researchers have argued that the firm stakeholders are as interested in timely information on gains as on timely information on losses, and so question the merits of the one-sided approach of conservatism. The implication is that, for instance, lenders not only care about losses but also about potentially offsetting gains. However, this view fails to consider that lenders' payoffs are asymmetric as they do not receive returns above the face value of the debt. When the value of the firm is well above the value of debt, lenders are hardly interested in gains. On the contrary, lenders fully participate in losses when the value of the firm falls below the value of the debt. Then, lenders are particularly interested in timely information about losses so that they can exercise legal actions to remove incumbent management and take control of the firm. Hence, their demand for timely information on gains is expected to be small relative to the demand for timely information on losses. Similarly, shareholders are expected to demand conditionally conservative accounting numbers. Conservative accounting aligns the interests of managers and shareholders, reducing the tendency of managers with short-term horizons to invest in negative-NPV (net present value) projects, because managers are aware that they will not be able to defer the recognition of losses to the future. In addition, conservative accounting imposes greater costs to biasing financial reports upwards (Guay and Verrecchia, 2006), and can thus be used as a mechanism to motivate managers to cut losses earlier and abandon poorly performing projects. Watts (2003a) also 
points out that conservatism prevents overcompensation of managers. All of these favourable outcomes of conservatism contribute to increase firm value and create barriers to the expropriation of shareholders by managers.

Corporate governance mechanisms in general and boards of directors in particular, are created to monitor managers. The demand for these mechanisms appears because of the existence of agency conflicts among the different parties to the firm, and particularly, because of the asymmetries in the incentives and objectives of managers and providers of finance derived from the separation of ownership and control (e.g. Berle and Means, 1932; Jensen and Meckling, 1976). When the design of these mechanisms and provisions permits efficient monitoring by the board of directors, it is expected that good governance will result, among other effects, in (i) higher financial statement transparency; (ii) lower accounting manipulation particularly lower income-increasing earnings management and therefore, in (iii) a limitation of the ability of managers to conceal bad news for a long period of time; (iv) greater independence of the committees destined to monitor management, such as the audit, the remuneration or the nomination committee; and finally (v) greater support from internal governance mechanisms to the expected auditor conservative bias.

Thus, stronger corporate governance is expected to result in a higher demand for timely information and to prevent managers from hiding less favourable information. Timely information on losses acts as a warning signal to the board of directors, who can investigate the origin of bad news as soon as it is known, lowering the agency costs derived from the monitoring of contracts.

We predict that board of directors' structure and characteristics significantly determine firm conditional conservatism, both via the increased demand for conservative accounting numbers and by mitigating aggressive accounting practices. Specifically, we expect that firms with strong governance mechanisms in place will be more conservative, as defined by Basu (1997) and by Ball and Shivakumar (2005).

\section{Research Method}

\subsection{Corporate Governance Measures: Board of Directors' Characteristics}

To measure the level or quality of firms' governance, we develop an aggregate index following the method of Bertrand and Mullainathan (2001). We calculate two aggregate indexes (IndGov6 and IndGov8) that incorporate several characteristics of the functioning and structure of the board of directors. IndGov6 combines the following proxies:

(1) The proportion of non-executive directors on the board. Clearly, a higher proportion of executive directors on the board is associated to a lower influence of independent members of the board and therefore, to a higher CEO 
influence over corporate governance. Non-executive directors include independent directors and directors representing institutional investors.

(2) The proportion of independent directors on the board. Previous research on the area shows that independent directors positively influence board decisions. Weisbach (1988) shows that the presence of outside directors is directly associated to CEO changes perhaps because these firms' boards are more independent of management. Byrd and Hickman (1992) show that bidding firms with a majority of outsiders in their boards obtain higher abnormal returns than other bidders.

(3) The fact that the chairman of the board is also an executive director can be interpreted as a higher implication of the CEO in firm governance and thus, as a sign of weak governance. We assign a value of 1 to this variable if the chairman is not an executive director (a sign of good governance); 0 otherwise.

(4) Number of board meetings. Vafeas (1999) and Adams (2000) suggest that the number of board meetings acts as a proxy of the level of real monitoring and control exerted by directors. Higher values of this variable are therefore indicative of more effective boards.

(5) Existence of an audit committee. The existence of an audit committee is associated to increases in the control and monitoring exerted by directors, and with an increase in the quality and transparency of financial statements (Klein, 2002; Xie et al., 2003). ${ }^{4}$

(6) Existence of a nomination/remuneration committee: the Olivencia Report recommends the existence of at least two separate board committees: an audit committee and a nomination/remuneration committee. These committees guarantee the efficiency of independent board members and act as CEO monitors. As demonstrated by Dechow et al. (1994), remuneration committees adjust CEO compensation to prevent opportunistic behaviour, and particularly, for the case of Spain, García Osma and Gill de Albornoz (2007) provide evidence of the importance of having a nomination/remuneration committee to guarantee earnings quality.

Our second measure of governance, IndGov8, incorporates all the six variables that form IndGov6, plus two additional variables that have a more controversial link with firm corporate governance:

(7) Lack of an executive committee. Although the existence of an executive committee may appear to improve corporate governance, the Olivencia Report considers that the existence of an executive committee impairs good governance, because this committee naturally assumes a significant role in decision making, lowering the importance of having independent directors or independent committees. Therefore, this variable takes the value of 1 if the firm does not have an executive committee (a sign of good governance); 0 otherwise. 
(8) Board size: Yermack (1996), Conyon and Peck (1998) and Eisenberg et al. (1998) suggest that the over dimension of boards has a negative impact on firm value. Several studies have tried to approximate the optimal board size. Jensen (1993) suggests that the optimal board size is between seven and eight members. The Olivencia Report purports an optimal size of between 5 and 15 directors. In our sample, no firm has less than five directors. Therefore, following the recommendations of the Olivencia Report, board size takes the value of 1 (good governance) if there are less than 16 directors on the board; 0 otherwise.

Following Bertrand and Mullainathan (2001), we define our aggregate governance measures (IndGov6 and IndGov8) as the mean of the six (eight) standardized variables. ${ }^{5}$ By standardizing the variables the tests should not be affected by scale problems associated to differences in the measurement of the variables that make up the indexes. ${ }^{6}$ It is expected that lower values of IndGov6 and IndGov8 will be associated to structures where the CEO has a high influence over the board of directors. For brevity, we refer to these structures as weak governance. Governance structures with low CEO implication in board decision making are denoted strong governance. This is the meaning we attach to the classification of strong vs. weak governance throughout the paper.

Recent literature provides evidence that the use of indexes that aggregate several governance measures allows classifying firms in accordance to the strength of their governance more successfully (see, e.g. Gompers et al., 2003; Davila and Penalva, 2006). This is because firm governance consists of numerous mechanisms, instruments and provisions that guarantee good governance when acting together. These various mechanisms complement each other, and therefore, any attempt to evaluate the quality of firm corporate governance should consider a broad set of variables to discriminate between strong and weak governance structures. Additionally, as demonstrated by recent research, Spanish outside directors appear to have had low efficiency during the first phase of the implementation of good governance recommendations. In particular, it has been documented that the mere presence of outside directors on Spanish boards has been insufficient to guarantee higher financial statement quality. The study by García Osma and Gill de Albornoz (2007) for instance, shows that the existence of independent remuneration committees significantly increases the efficiency of independent directors in limiting earnings management practices.

\subsubsection{Controlling for the endogenous nature of governance}

The appropriate level of governance is a function of firms' characteristics, as different types of firms require different levels of governance. Therefore, not taking into account the economic determinants of governance may lead to 
incorrect inferences. Accordingly, we adopt the view that observed governance structures capture optimal contracting arrangements, determined endogenously by firms' characteristics and contracting environment. To account for these factors, we develop a model of hypothesized economic determinants of governance using the findings of previous research. We predict that governance will be determined by the following variables:

(a) Size. Larger firms are more complex to run and place higher demands on governance structures (Demsetz and Lehn, 1985). We measure size as the natural logarithm of the market value of equity, measured at the end of the fiscal year, and predict a positive association between Size and our governance proxies, IndGov\#.

(b) Growth opportunities. Growing firms need more flexible governance structures, and more room for individual decisions by the entrepreneur. Consequently, we expect a negative relation between governance and growth. Following Smith and Watts (1992), our proxy for growth is the market-to-book value of equity ratio, measured at the end of the fiscal year $(M T B)$.

(c) Profitability. Previous research documents an association between certain governance attributes and past firm performance. Hermalin and Weisbach (1998) find that the likelihood of independent directors being added to the board increases following poor firm performance. We measure Profitability as the ratio of net income to shareholders' equity.

(d) Leverage. In a civil-law context such as Spain, financial institutions play a key role in providing capital funds, and are represented in the board of directors as institutional directors. We expect that as leverage increases, monitoring by financial institutions will also increase leading to improved governance provisions. Consequently, we expect a positive association between leverage and IndGov\#. We measure Leverage as the debt to assets ratio. The relation between Leverage and governance has been previously studied by Cremers and Nair (2005), among others.

(e) Changes in ownership. There is extensive research on the association between ownership structure and governance (Demsetz and Lehn, 1985; Bushman et al., 2004) and on how events such as mergers and acquisitions, IPOs, SEOs and other important changes in the ownership structure may affect governance and accounting quality (Rangan, 1998; Teoh et al., 1998a, 1998b). Following Chung et al. (2003) and Cahan and Zhang (2006), we assume that if there is an annual change greater than $10 \%$ in the number of shares outstanding, an event such as a takeover or a merger has taken place. Thus, we define an indicator variable (Changes Ownership) that equals 1 if there is an annual change in the number of shares outstanding greater than $10 \%$, and 0 otherwise. 
To take into account the endogenous nature of governance choice, we estimate the following cross-sectional model of the economic determinants of governance:

$$
\begin{aligned}
\text { IndGov\# }_{i t}= & \beta_{0}+\beta_{1} \text { Size }_{i t}+\beta_{2} \text { MTB }_{i t}+\beta_{3} \text { Profitability }_{i t}+\beta_{4} \text { Leverage }_{i t} \\
& +\beta_{5} \text { Change ownership }_{i t}+\sum \alpha_{i}+\sum \delta_{t}+\mu_{i t}
\end{aligned}
$$

All variables are defined as explained. We also include firm $\left(\alpha_{i}\right)$ and year $\left(\delta_{t}\right)$ dummies in the analysis. The residuals from this regression are denoted Gov6 or Gov8, depending on the IndGov\# indicator used. These residuals capture the level of governance orthogonal to firm characteristics and fiscal year. Higher values of Gov6 or Gov8 are associated to stronger governance structures. We use Gov6 and Gov8 as our main proxy of the characteristics of the board of directors. Firms with high (low) values of Gov\# are those with low (high) CEO involvement in board decisions, which we refer to as firms with strong (weak) governance.

\subsection{Accounting Conservatism Measure}

Accounting conservatism is measured initially using the Basu (1997) model. Basu's measure of accounting conservatism is based on the idea that conservatism generates earnings that reflect bad news faster than good news due to the asymmetric accounting requirements for the verification and recognition of gains and losses. Basu uses market returns as his proxy for the existence of good and bad news during the period. Prices incorporate all the information arriving at the market from many sources beyond accounting data. Thus, changes in prices during the period (returns) are a good measure of the arrival of news to the market. Because earnings capture bad news in a timelier fashion than good news, Basu predicts that there will be a higher association between earnings and returns when returns are negative (his proxy for bad news), than when returns are positive (his proxy for good news). The Basu model is as follows:

$$
X_{i t}=\beta_{0}+\beta_{1} D_{i t}+\beta_{2} \operatorname{Ret}_{i t}+\beta_{3} D_{i t} \operatorname{Ret}_{i t}+u_{i t}
$$

where $i t$ are firm-year indicators, $X$ is earnings per share after extraordinary items divided by the beginning-of-period price. Ret is the rate of return for the period, $D$ is a dummy variable that takes the value of 1 if there is bad news (when the return is negative or zero); 0 if there is good news (positive return). ${ }^{7}$ The $\beta_{3}$ coefficient measures the asymmetric recognition speed of bad news in earnings the level of conservatism and is expected to be significantly positive.

Some authors have raised concerns about the use of the Basu method to measure the asymmetric timeliness of earnings. In particular, Dietrich et al. (2007) show that partitioning a regression sample with one of the regressors may produce biased inferences. They also argue that inferences from Basu's 
regression might be biased due to earnings driving returns. For these reasons, they suggest the use of alternative measures to validate the robustness of inferences drawn with the Basu approach. We do so in Section 5.3 below by using the Ball and Shivakumar (2005) measure which is entirely accounting-based. Nevertheless, despite these concerns, Ryan (2006, footnote 2) argues that the biases introduced by the Basu approach are likely to be small. ${ }^{8}$ Following Ryan (2006), to ameliorate these concerns we measure returns over the fiscal year. This partially removes the impact of the annual earnings announcement over stock prices, which occurs several months after closing. ${ }^{9}$

To study the differential conservatism across governance structures we will use the following adaptation of the Basu model in which we interact our governance proxy with all the variables in the original model (2):

$$
\begin{aligned}
X_{i t}= & \beta_{0}+\beta_{1} D_{i t}+\beta_{2} \text { Gov\# }_{i t}+\beta_{3} D_{i t} \text { Gov\# }_{i t}+\beta_{4} R_{i t}+\beta_{5} \text { Ret }_{i t} \text { Gov\# }_{i t} \\
& +\beta_{6} D_{i t} \text { Ret }_{i t}+\beta_{7} D_{i t} \text { Ret }_{i t} \text { Gov\# }_{i t}+\sum \alpha_{t}+u_{i t}
\end{aligned}
$$

where Gov\# is our aggregate corporate governance measure orthogonal to firm characteristics and $\sum \alpha_{t}$ are year dummies. Our prediction is that the coefficient that measures the interaction between conservatism and governance $\left(\beta_{7}\right)$ will be significantly positive, consistent with better governed firms showing a higher level of conditional conservatism. Additionally, we control for differences in firm growth opportunities as measured by the market-to-book value of equity ratio $(M T B)$ following the approach of Roychowdhury and Watts (2007). In particular, we augment equation (3) by interacting the explanatory variables with the market-to-book ratio as follows:

$$
\begin{aligned}
X_{i t}= & \beta_{0}+\beta_{1} D_{i t}+\beta_{2} \operatorname{Gov6}_{i t}+\beta_{3} D_{i t} \text { Gov6 }_{i t}+\beta_{01} \text { MTB }_{i t}+\beta_{11} \text { MTB }_{i t} D_{i t} \\
& +\beta_{21} \text { MTB }_{i t} \text { Gov6 }_{i t}+\beta_{31} M T B_{i t} D_{i t} \text { Gov6 }_{i t}+\beta_{4} \operatorname{Ret}_{i t}+\beta_{5} \operatorname{Ret}_{i t} \text { Gov6 }_{i t} \\
& +\beta_{41} \text { MTB }_{i t} \operatorname{Ret}_{i t}+\beta_{51} \text { MTB }_{i t} \operatorname{Ret}_{i t} \text { Gov6 }_{i t}+\beta_{6} D_{i t} \operatorname{Ret}_{i t}+\beta_{7} D_{i t} \operatorname{Ret}_{i t} \text { Gov }_{i t} \\
& +\beta_{61} \text { MTB }_{i t} D_{i t} R_{i t}+\beta_{71} M B_{i t} D_{i t} \operatorname{Ret}_{i t} \text { Gov6 }_{i t}+\sum \alpha_{t}+u_{i t}
\end{aligned}
$$

It is important to control for these growth differences, because changes in growth opportunities can create variations in the asymmetric timeliness of earnings that are unrelated to accounting conservatism (Roychowdhury and Watts, 2007). The aim of our study is not to estimate the level of conservatism of each type of governance structure, but to determine if there are significant differences in the level of conservatism across governance structures, once we have controlled for differences in growth opportunities. The market-to-book ratio also acts as a proxy of unconditional or balance-sheet conservatism, that is, of the persistent understatement of net assets derived from the use of historical cost accounting or the non-recognition of intangible assets. Pope and Walker (2003) and 
Beaver and Ryan (2005) purport that firms that understate their net assets are likely to be less earnings conservative, as bad news has been anticipated. Because unconditional conservatism pre-empts conditional conservatism, it is important to control for the potential understatement of net assets in our tests, to ensure that comparisons across weak and strong governance structures are not driven by differences in the use of unconditional conservatism.

\section{Sample Selection Procedure}

Accounting and market data are downloaded from Bureau Van Dijk Osiris. Corporate governance data are obtained from SpencerStuart. ${ }^{10}$ To limit the influence of extreme observations, we delete the top and bottom percentiles of the distribution of returns $(R)$ and scaled earnings $(X) .{ }^{11}$ Following extant research in this area, we delete financial firms from our sample, as their accounting data is not comparable to the rest of the sample firms. The intersection of these databases results in a final sample of 193 firm-year observations corresponding to 69 separate Spanish firms for the period 19972002 with complete data to run all the tests. Out of the 193 observations, 28 are firms that operate in the primary sector and construction, 98 operate in the secondary industry (manufacturing), 50 are transportation, communication and public service firms, and the remaining 17 are service and retailing companies. Regarding the annual distribution of the observations, 16 belong to 1997,16 to 1998,26 to 1999,35 to 2000, 53 to 2001 and 47 to 2002.

Table 1 contains sample descriptive statistics. The descriptive statistics show that, on average, $79 \%$ of the directors are non-executives, $36 \%$ of all directors are independent and the board meets 9 times a year. We can also see that $64 \%$ $(62 \%)$ of the firms have an audit committee (nomination/remuneration committee), $51 \%$ of the firms do not have an executive committee and $82 \%$ of the firms have a board size of 15 or less components, as recommended by the Olivencia Report. Finally, in $28 \%$ of the firms, the CEO is also an executive director. Consistent with the existence of conditional conservatism, that is, with the asymmetric timeliness of earnings, earnings are negatively skewed (the medians are greater than the means). As expected, we also observe that the standard deviation of returns is greater than the standard deviation of earnings, and that accruals are on average negative due to the effect of amortization and depreciation. Table 2 presents the correlation matrix. We observe a very high correlation between IndGov6 and IndGov8. The two variables we exclude from IndGov8 to build IndGov6 (the lack of an executive committee and whether the board is formed by less than 15 members) are not correlated with IndGov6. This likely confirms our expectation that board size and the existence of an executive committee are potentially less reliable measures of corporate governance, as they are not correlated with the remaining well-documented governance factors that make up IndGov6. This could be interpreted as IndGov6 being a more reliable measure of governance quality. ${ }^{12}$ 
Table 1. Descriptive statistics

\begin{tabular}{|c|c|c|c|c|c|c|}
\hline Variable definition & Variable & Mean & St. dev. & Perc. 25 & Median & Perc. 75 \\
\hline Earnings per share & $X$ & 0.06 & 0.09 & 0.04 & 0.07 & 0.10 \\
\hline Share return & Ret & 0.01 & 0.35 & 0.23 & 0.04 & 0.19 \\
\hline Total accruals & $A C C R$ & 0.05 & 0.02 & 0.06 & 0.05 & 0.04 \\
\hline $\begin{array}{l}\text { Cash flows from } \\
\text { operations }\end{array}$ & $C F$ & 0.10 & 0.06 & 0.06 & 0.09 & 0.13 \\
\hline $\begin{array}{l}\text { Size (log of market value } \\
\text { of equity) }\end{array}$ & Size & 13.56 & 1.68 & 12.18 & 13.77 & 14.65 \\
\hline $\begin{array}{l}\text { Profitability (earnings/ } \\
\text { equity) }\end{array}$ & Profitability & 0.08 & 0.40 & 0.06 & 0.11 & 0.16 \\
\hline Leverage (debt/assets) & Leverage & 0.62 & 0.18 & 0.51 & 0.65 & 0.76 \\
\hline Change in ownership & Change ownership & 0.09 & 0.29 & 0 & 0 & 0 \\
\hline Market to book ratio & $M T B$ & 2.36 & 2.83 & 1.05 & 1.61 & 2.27 \\
\hline $\begin{array}{l}\text { Aggregate Corp. Gov. } \\
\text { Index }\end{array}$ & IndGov6 & 0.38 & 0.27 & 0.19 & 0.42 & 0.57 \\
\hline $\begin{array}{l}\text { Aggregate Corp. Gov. } \\
\text { Index }\end{array}$ & IndGov8 & 0.37 & 0.20 & 0.23 & 0.36 & 0.53 \\
\hline $\begin{array}{l}\text { Aggregate Corp. Gov. } \\
\text { Index }\end{array}$ & Gov6 & 0.00 & 0.21 & 0.11 & 0 & 0.10 \\
\hline $\begin{array}{l}\text { Aggregate Corp. Gov. } \\
\text { Index }\end{array}$ & Gov8 & 0.00 & 0.17 & 0.09 & 0 & 0.08 \\
\hline$\%$ non executive directors & Propnonexe & 0.79 & 0.13 & 0.73 & 0.82 & 0.88 \\
\hline$\%$ independent directors & Propindep & 0.36 & 0.23 & 0.20 & 0.36 & 0.50 \\
\hline Chairman is an executive & Chairnonexe & 0.28 & 0.45 & 0.00 & 0.00 & 1.00 \\
\hline Number of board meetings & Nmeetings & 9.04 & 3.23 & 6.00 & 9.00 & 12.00 \\
\hline $\begin{array}{l}\text { Audit committee } \\
\text { existence }\end{array}$ & Audicom & 0.64 & 0.48 & 0.00 & 1.00 & 1.00 \\
\hline $\begin{array}{l}\text { Nom./retribution } \\
\text { committee }\end{array}$ & Retricom & 0.62 & 0.49 & 0.00 & 1.00 & 1.00 \\
\hline $\begin{array}{l}\text { Lack of executive } \\
\text { committee }\end{array}$ & No Execom & 0.51 & 0.50 & 0.00 & 1.00 & 1.00 \\
\hline Board size smaller than 16 & Board15orless & 0.82 & 0.38 & 1.00 & 1.00 & 1.00 \\
\hline
\end{tabular}

The sample consists of 193 firm year observations for the period 1997 2002, corresponding to 69 firms. $X$ is earnings per share after extraordinary items divided by beginning of period price. Ret is annual return. ACCR are total accruals scaled by beginning of period total assets, $C F$ are cash flows from operations divided by beginning of period total assets. Size equals the natural $\log$ of the market value of equity at fiscal year end. Profitability is measured as net income divided by share holders' equity at fiscal year end. Leverage is total debt divided by total assets at fiscal year end. Change ownership is an indicator variable that equals 1 if there is an annual change in the number of shares outstanding greater than $10 \%$, and 0 otherwise. MTB is the market to book value of equity ratio at the end of the year. IndGov6 and IndGov 8 are aggregate indexes that measure govern ance quality. Higher values of the index are associated to stronger governance. Propnonexe is the pro portion of non executive directors. Propindep is the proportion of independent directors. Chairnonexe takes the value of 1 if the chairman of the board is not an executive; 0 otherwise. Nmeetings is the number of board meetings. Audicom takes the value of 1 if the firm has an audit committee; 0 other wise. Retricom takes the value of 1 if the firm has a nomination/remuneration committee; 0 otherwise. No Execom takes the value of 0 if there is an executive committee; 1 otherwise. Board15orless takes the value of 1 if there are less than 16 directors on the board; 0 otherwise. 
Table 2. Correlation matrix

\begin{tabular}{|c|c|c|c|c|c|c|c|c|c|c|c|c|c|c|}
\hline & $X$ & Ret & $A C C R$ & $C F$ & $M T B$ & IndGov6 & IndGov8 & Propnonexe & Propindep & Chairnonexe & Nmeetings & Audicom & Retricom & No Execom \\
\hline Ret & 0.29 & & & & & & & & & & & & & \\
\hline$A C C R$ & 0.00 & 0.07 & & & & & & & & & & & & \\
\hline$C F$ & 0.47 & 0.11 & -0.58 & & & & & & & & & & & \\
\hline MTB & -0.07 & -0.07 & -0.03 & 0.25 & & & & & & & & & & \\
\hline IndGov6 & -0.02 & -0.08 & -0.09 & -0.05 & -0.03 & & & & & & & & & \\
\hline IndGov8 & -0.04 & -0.09 & -0.10 & 0.01 & -0.00 & 0.89 & & & & & & & & \\
\hline Propnonexe & 0.10 & -0.08 & -0.31 & 0.13 & 0.00 & 0.49 & 0.40 & & & & & & & \\
\hline Propindep & -0.01 & -0.05 & 0.10 & -0.14 & 0.08 & 0.49 & 0.49 & 0.03 & & & & & & \\
\hline Chairnonexe & -0.17 & -0.01 & -0.12 & 0.01 & -0.03 & 0.36 & 0.34 & 0.16 & -0.13 & & & & & \\
\hline Nmeetings & 0.09 & 0.04 & 0.23 & -0.17 & 0.05 & 0.49 & 0.38 & 0.23 & 0.03 & 0.16 & & & & \\
\hline Audicom & -0.05 & -0.07 & -0.07 & -0.04 & -0.10 & 0.76 & 0.72 & 0.19 & 0.32 & 0.01 & 0.18 & & & \\
\hline Retricom & 0.00 & -0.09 & -0.15 & 0.06 & -0.10 & 0.73 & 0.64 & 0.16 & 0.26 & 0.03 & 0.13 & 0.74 & & \\
\hline No Execom & -0.01 & -0.05 & -0.09 & 0.14 & -0.03 & 0.09 & 0.45 & 0.01 & -0.13 & 0.06 & 0.09 & 0.12 & 0.04 & \\
\hline Board15orless & -0.09 & -0.00 & -0.01 & 0.05 & 0.04 & -0.02 & 0.34 & -0.14 & 0.14 & 0.05 & -0.12 & 0.05 & -0.05 & 0.36 \\
\hline
\end{tabular}

The sample consists of 193 firm year observations for the period 1997 2002, corresponding to 69 firms. $X$ is earnings per share after extraordinary items divided by beginning of period price. Ret is annual return. ACCR are total accruals divided by total assets in $t-1$. $C F$ is cash flows from operations divided by total assets in $t-1 . M T B$ is the market to book equity ratio at the end of the year. IndGov6 and IndGov8 are aggregate indexes that measure governance quality. Higher values of the index are associated to stronger governance. Propnonexe is the proportion of non executive directors. Propindep is the proportion of independent directors. Chairnonexe takes the value of 1 if the chairman of the board is not an executive; 0 otherwise. Nmeetings is the number of board meetings. Audicom takes the value of 1 if the firm has an audit $\quad 0$ otherwise. Retricom takes the value of 1 if the firm has a nomination/remuneration committee; 0 otherwise. No Ex ecom takes the value of 0 if there is an executive committee; 1 otherwise. Board15orless takes the value of 1 if there are less than 16 directors on the board; 0 otherwise. 


\section{Empirical Results}

\subsection{Differences in Conservatism across Governance Structures}

For parsimony, in what follows we only report and discuss the results obtained using the governance index Gov6, as all the inferences hold when we use the alternative index Gov8. ${ }^{13}$

Table 3 shows the results of running equation (1) with IndGov6 as the dependent variable. We use the residuals (Gov6) of equation (1) as our main measure of governance quality (a governance proxy that is orthogonal to firm characteristics). Because governance is to a certain extent endogenously determined, controlling for firm characteristics has become usual practice when analysing the relation between governance and accounting numbers (see Bushman et al., 2004; García Lara et al., 2009, among others). The explanatory power of regression (1) is high (adjusted $R^{2} \quad 74 \%$ ) and the signs of the coefficients are consistent with expectations: governance provisions are stronger for larger and more levered firms, and weaker for growing and highly profitable firms. We find similar results when using IndGov8 as the dependent variable. ${ }^{14}$

To analyse the difference in conservatism across governance structures we estimate equation (3). Table 4 shows the results of this estimation using Gov6 as our aggregate corporate governance index. Consistent with prior research on asymmetric timeliness of earnings in European countries, the good news

Table 3. Regression on economic determinants of governance IndGov6 $_{i t}=\beta_{0}+\beta_{1}$ Size $_{i t}+\beta_{2}$ MTB $_{i t}+\beta_{3}$ Profitability $_{i t}+\beta_{4}$ Leverage $_{i t}$ $+\beta_{5}$ Change ownership $i t+\Sigma \alpha_{i}+\Sigma \delta_{t}+\mu_{i t}$

\begin{tabular}{lllr}
\hline & & Coeff. & $t$ Stat. \\
\hline Intercept & $\beta_{0}$ & 3.89 & 2.59 \\
Size & $\beta_{1}$ & 0.23 & 2.09 \\
Market to book & $\beta_{2}$ & 0.05 & 1.14 \\
Profitability & $\beta_{3}$ & 0.06 & 0.42 \\
Leverage & $\beta_{4}$ & 0.79 & 1.69 \\
Change ownership & $\beta_{5}$ & 0.03 & 0.33 \\
Firm dummies & & Yes & \\
Year dummies & & Yes & \\
Adjusted $R^{2}$ & & 0.74 & \\
$F$ Value (Prob $>F)$ & & $5.55(0.00)$ & \\
No. observations & & 193 & \\
\hline
\end{tabular}

The sample consists of 193 firm year observations for the period 1997 2002, corresponding to 69 firms. IndGov6 is an aggregate index that measures governance quality. Size is the natural logarithm of market value. Market to book is the ratio of market capitalization divided by shareholders' equity. Profitability is earnings divided by shareholders' equity at fiscal year end. Leverage is total debt divided by total assets at fiscal year end. Change ownership is a dummy variable taking the value of 1 if there is an annual change greater than $10 \%$ in the number of shares outstanding, and 0 other wise. $\Sigma \alpha_{i}$ and $\Sigma \delta_{t}$ stand for firm specific and year specific dummy variables, respectively. Regression results for these variables are omitted for parsimony. 
Table 4. Measuring accounting conservatism: corporate governance effects controlling for firm economic characteristics. Comparison of the level of accounting conservatism across governance structures:

$$
\begin{gathered}
X_{i t}=\beta_{0}+\beta_{1} D_{i t}+\beta_{2} \text { Gov6 }_{i t}+\beta_{3} D_{i t} \text { Gov6 }_{i t}+\beta_{4} \text { Ret }_{i t}+\beta_{5} \text { Ret }_{i t} \text { Gov6 }_{i t} \\
+\beta_{6} D_{i t} \text { Ret }_{i t}+\beta_{7} D_{i t} \text { Ret }_{i t} \text { Gov6 }_{i t}+\Sigma \alpha_{t}+u_{i t}
\end{gathered}
$$

\begin{tabular}{lll}
\hline Intercept & $\beta_{0}$ & 0.05 \\
$D$ & $t$ stat & 2.04 \\
& $\beta_{1}$ & 0.04 \\
Gov6 & $t$ stat & 1.90 \\
& $\beta_{2}$ & 0.04 \\
$D$ Gov6 & $t$ stat & 0.51 \\
& $\beta_{3}$ & 0.07 \\
Ret & $t$ stat & 0.77 \\
& $\beta_{4}$ & 0.07 \\
Ret Gov6 & $t$ stat & 1.43 \\
& $\beta_{5}$ & 0.10 \\
$D$ Ret & $t$ stat & 0.77 \\
& $\beta_{6}$ & 0.15 \\
$D$ Ret Gov6 & $t$ stat & 1.89 \\
& $\beta_{7}$ & 0.59 \\
Adj $R^{2}$ & $t$ stat & 2.17 \\
$F$ Value (Prob $>F)$ & & 0.11 \\
No. observations & & 5.05 \\
\hline
\end{tabular}

The sample consists of 193 firm year observations for the period 1997 2002, corresponding to 69 firms. Gov6 is an aggregate measure of corporate governance quality: the residuals from a regression of IndGov6 on a set of variables that measure firm characteristics: (i) size, (ii) market to book ratio, (iii) profitability, (iv) leverage, (v) changes in ownership, and firm and year dummies. The residuals from these regressions are denoted Gov6, and they reflect governance quality orthogonal to these firm characteristics. Higher values of the index are associated to stronger governance. $X$ is earnings per share scaled by beginning of period price, Ret is annual return, $D$ is a dummy variable that takes the value of 0 if Ret is positive; 1 otherwise. $\Sigma \alpha_{t}$ represent year dummies (not reported for parsimony). Reported $t$ statistics are calculated using the Huber White variance covariance matrix, and are robust to the presence of heteroscedasticity and serial correlation (Rogers, 1993).

coefficient $\left(\beta_{4}\right)$ is positive, and significant in a one-sided test ( $p$-value $<0.08$ ). The sign of the differential good news recognition speed in good governed firms $\left(\beta_{5}\right)$ is, as expected, negative (albeit insignificant). A negative sign is consistent with good governed firms not recognizing good news faster than weak governance firms. Consistent with the existence of conservatism in all firms, the $\beta_{6}$ coefficient, which captures the additional recognition speed of bad news with respect to good news, is significantly positive. Finally, the significantly positive $\beta_{7}$ coefficient captures our main result: good governed firms (firms with stronger boards) show more conditionally conservative accounting numbers. ${ }^{15}$ This result is robust to several different specifications: (a) excluding regulated firms from the analysis (SIC code 49, losing 32 firm-year observations); (b) splitting the sample between strong and weak governed firms using Gov6, Gov8, IndGov6 or IndGov8; (c) excluding from the sample firms that are cross-listed, 
as they may have different incentives to be conditionally conservative; and (d) excluding from the sample the observations from 1997 and 1998 to avoid the confounding effects of the regulatory changes introduced by the Olivencia Report. The difference in the conservatism coefficient across strong and weak governance firms is always significant and greater for strong governance firms; (e) replicating equation (3) not including year dummies; and (f) replicating equation (3) using Gov8 or IndGov8 as governance indexes. The year dummies are insignificant across all specifications. These results are obtained pooling all data together. Table 5 presents the results of estimating equation (3) using Fama and MacBeth (1973) mean annual regressions. The use of the Fama MacBeth approach has become standard in the accounting literature to

Table 5. Measuring accounting conservatism: corporate governance effects controlling for firm economic characteristics. Fama MacBeth (1973) regressions. Comparison of the level of accounting conservatism across governance structures:

$$
\begin{array}{r}
X_{i t}=\beta_{0}+\beta_{1} D_{i t}+\beta_{2} \text { GovG }_{i t}+\beta_{3} D_{i t} \text { Gov6 }_{i t}+\beta_{4} \operatorname{Ret}_{i t}+\beta_{5} \operatorname{Ret}_{i t} \text { Gov6 }_{i t} \\
+\beta_{6} D_{i t} \operatorname{Ret}_{i t}+\beta_{7} D_{i t} \operatorname{Ret}_{i t} \text { Gov6 }_{i t}+\Sigma \alpha_{t}+u_{i t}
\end{array}
$$

\begin{tabular}{llr}
\hline Intercept & $\beta_{0}$ & 0.05 \\
$D$ & $t$ stat & 6.99 \\
& $\beta_{1}$ & 0.05 \\
Gov6 & $t$ stat & 1.52 \\
& $\beta_{2}$ & 0.15 \\
$D$ Gov6 & $t$ stat & 1.44 \\
& $\beta_{3}$ & 0.02 \\
Ret & $t$ stat & 0.14 \\
& $\beta_{4}$ & 0.09 \\
Ret Gov6 & $t$ stat & 1.96 \\
& $\beta_{5}$ & 0.33 \\
D Ret & $t$ stat & 1.90 \\
& $\beta_{6}$ & 0.22 \\
D Ret Gov6 & $t$ stat & 1.29 \\
& $\beta_{7}$ & 1.20 \\
Adj $R^{2}$ & $t$ stat & 2.42 \\
No. observations & & 0.14 \\
\hline
\end{tabular}

The sample consists of 193 firm year observations for the period 1997 2002, corresponding to 69 firms. Gov6 is an aggregate measure of corporate governance quality: the residuals from a regression of IndGov6 on a set of variables that measure firm characteristics: (i) size, (ii) market to book ratio, (iii) profitability, (iv) leverage, (v) changes in ownership, and firm and year dummies. The residuals from these regressions are denoted Gov6, and they reflect governance quality orthogonal to these firm characteristics. Higher values of the index are associated to stronger governance. $X$ is earnings per share scaled by beginning of period price, Ret is annual return, $D$ is a dummy variable that takes the value of 0 if Ret is positive; 1 otherwise. $\Sigma \alpha_{t}$ represents year dummies (not reported for parsi mony). We use the Fama and MacBeth (1973) methodology to cope with the possible cross sectional dependence problems. The coefficients of the parameters have been obtained as the simple average from annual cross section regressions. The $t$ statistics are the ratios of the mean estimated coefficients to the standard deviation of the distribution of the annual estimated slope coefficients, divided by the square root of the number of years. 
cope with cross-sectional dependence problems. Although its use with reduced samples, such as our case, might not yield robust estimates because of the reduced number of observations per annual regression, our results using the Fama MacBeth approach confirm those of the pooled analysis: firms with stronger boards are more conditionally conservative, as captured by a positive and significant $\beta_{7}$ coefficient.

\subsection{Influence of Growth Opportunities on the Level of Conservatism}

Roychowdhury and Watts (2007) show the importance of controlling for differences in growth opportunities when measuring conservatism. Changes in growth opportunities can affect accounting conservatism estimates and introduce differences that are not related to the asymmetric incorporation of news into earnings. To ensure that our results are not driven by differences in growth opportunities across governance structures, we augment equation (3) by interacting the explanatory variables with the market-to-book ratio (similarly to Roychowdhury and Watts, 2007) yielding equation (4). We use the market-to-book ratio $(M T B)$ as a proxy of growth opportunities. This ratio acts as well as a proxy of the level of unconditional conservatism, that is, of the understatement of net assets.

Table 6 shows the results of this test. For brevity, we only reproduce the coefficients of interest in the table. Our previous inferences do not change after controlling for the market-to-book ratio: stronger governance structures (firms with stronger boards) show more conditionally conservative accounting numbers (positive and significant $\beta_{7}$ ). In addition, we also find negative $\beta_{61}$ and $\beta_{71}$ coefficients. We expect these coefficients to be negative because: (1) it is reasonable to assume that firms with high growth opportunities may need less stringent governance structures, or may have insider-dominated boards, since external directors with experience in managing growth opportunities are relatively scarce (Booth and Deli, 1996) and it is likely that independent directors will have less knowledge of the firm and its industry, making their presence less desirable in this type of firm (Bhagat and Black, 1999); and (2) it could be argued that firms showing high market-to-book ratios are also firms with high levels of unconditional conservatism. Unconditional conservatism pre-empts conditional conservatism reducing the empirical measures of asymmetric earnings timeliness (Pope and Walker, 2003; Beaver and Ryan, 2005).

\subsection{Sensitivity Check: Accruals-Based Measure of Accounting Conservatism}

A measure of conservatism that overcomes most of the limitations of the Basu approach (see Dietrich et al., 2007) is the one developed by Ball and Shivakumar (2005). These authors measure conservatism for a sample of private UK firms. Because prices are not available for private firms, they cannot use the Basu (1997) measure in their tests, and they develop an alternative measure of 
Table 6. Measuring accounting conservatism: differences in governance structures and growth opportunities

$X_{i t}=\beta_{0}+\beta_{1} D_{i t}+\beta_{2}$ Gov6 $_{i t}+\beta_{3} D_{i t} G_{0 v 6}+\beta_{01} M T B_{i t}+\beta_{11} M_{T B} D_{i t}+\beta_{21} M_{i t} B_{i t}$ Gov6 $_{i t}+\beta_{31}$ MTB $_{i t} D_{i t}$ Gov6 $_{i t}+\beta_{4}$ Ret $_{i t}+\beta_{5}$ Ret $_{i t}$ Gov6 $_{i t}+\beta_{41}$ MTB $_{i t}$ Ret $_{i t}+\beta_{51}$ $M T B_{i t}$ Ret $_{i t}$ Gov6 $_{i t}+\beta_{6} D_{i t}$ Ret $_{i t}+\beta_{7} D_{i t}$ Ret $_{i t}$ Gov6 $_{i t}+\beta_{61}$ MTB $_{i t} D_{i t}$ Ret $_{i t}+\beta_{71}$ MTB $_{i t}$ $D_{i t} \operatorname{Ret}_{i t}$ GovG $_{i t}+\Sigma \alpha_{t}+u_{i t}$

\begin{tabular}{lll}
\hline$R$ & $\beta_{4}$ & 0.08 \\
Ret Gov6 & $t$ stat & 0.80 \\
& $\beta_{5}$ & 0.44 \\
MTB Ret & $t$ stat & 0.90 \\
MTB Ret Gov6 & $\beta_{41}$ & 0.01 \\
& $t$ stat & 0.36 \\
Det & $\beta_{51}$ & 0.14 \\
& t stat & 0.83 \\
D Ret Gov6 & $\beta_{6}$ & 0.23 \\
& $t$ stat & 1.71 \\
MTB D Ret & $\beta_{7}$ & 1.70 \\
& $t$ stat & 2.33 \\
MTB D Ret Gov6 & $\beta_{61}$ & 0.04 \\
& $t$ stat & 1.08 \\
Adj $R^{2}$ & $\beta_{71}$ & 0.45 \\
$F$ Value (Prob $>F)$ & $t$ stat & 1.98 \\
No. observations & & 0.15 \\
& & $3.81(0.00)$ \\
\hline
\end{tabular}

The sample consists of 193 firm year observations for the period 1997 2002, corresponding to 69 firms. Gov6 is an aggregate measure of corporate governance quality: the residuals from a regression of IndGov6 on a set of variables that measure firm characteristics: (i) size, (ii) market to book ratio, (iii) profitability, (iv) leverage, (v) changes in ownership, and firm and year dummies. The residuals from these regressions are denoted Gov6, and they reflect governance quality orthogonal to these firm characteristics. Higher values of the index are associated to stronger governance. $X$ is earnings per share scaled by beginning of period price, Ret is annual return, $D$ is a dummy variable that takes the value of 0 if Ret is positive; 1 otherwise. MTB is the ratio of market capitalization to shareholders' equity. $\Sigma \alpha_{t}$ represent year dummies (not reported for parsimony). Reported $t$ statistics are calculated using the Huber White variance covariance matrix, and are robust to the presence of heteroscedas ticity and serial correlation (Rogers, 1993). We do not report the intercept and its interactions with the bad news dummy, the governance index and the MTB ratio for parsimony.

conditional conservatism based on the links between total accruals and operating cash flows. The intuition is the same as in the Basu model: accounting earnings tend to anticipate the recognition of bad news and to delay the recognition of good news. Total accruals and cash flows are negatively associated, as has been documented by previous research (e.g. Dechow, 1994); but this negative association, because of the asymmetric recognition of news in earnings, tends to be lower in periods with economic losses. Total accruals recognize the impact of negative economic events in the period they take place; these adverse effects tend to affect cash flows as well, lowering the negative correlation between cash flows and accruals. Ball and Shivakumar use the following 
regression to measure this association between cash flows and accruals:

$$
A C C R_{i t}=\beta_{0}+\beta_{1} D C F_{i t}+\beta_{2} C F_{i t}+\beta_{3} D C F_{i t} C F_{i t}+\mu_{i t}
$$

where $A C C R$ are total accruals scaled by beginning-of-period total assets, $C F$ are operating cash flows scaled by beginning-of-period total assets, $D C F$ is a dummy variable that takes the value of 1 if firm $C F$ is at the lower $5 \%$ of the distribution; 0 otherwise. This dummy variable captures the occasions when bad news (economic losses) has occurred during the period, lowering cash flows, that is, it captures situations when cash flows are negative or very low. ${ }^{16}$ In equation (5), $\beta_{2}$ is expected to be significantly negative, reflecting the negative association between cash flows and accruals, whilst $\beta_{3}$ is expected to be positive, indicating that economic losses are reflected both in cash flows and accruals at the same time. Ball and Shivakumar (2005) provide evidence consistent with their predictions, documenting that $\beta_{2}\left(\beta_{3}\right)$ is negative (positive).

To analyse the differences in conservatism across governance structures, we augment equation (5), interacting all explanatory variables with Gov6 in the following fashion:

$$
\begin{aligned}
& A C C R_{i t}=\beta_{0}+\beta_{1} D C F_{i t}+\beta_{2} \text { Gov }_{i t}+\beta_{3} D C F_{i t} G o v 6_{i t}+\beta_{4} C F_{t}+\beta_{5} C F_{i t} \text { Gov }_{i t} \\
& +\beta_{6} D C F_{i t} C F_{i t}+\beta_{7} D C F_{i t} C F_{i t} G o v \sigma_{i t}+\sum \alpha_{t}+u_{i t}
\end{aligned}
$$

where $\sum \alpha_{t}$ represent year indicator variables. Table 7 shows the results from estimating equation (6) using Gov6 as the aggregate governance measure. The results confirm that strong governance firms are clearly more conservative than weak governance firms: $\beta_{7}$ is significantly positive. If we repeat this test using Gov8, IndGov6 or IndGov8 as governance measures, our inferences do not change.

\section{Conclusions}

We analyse the association between conditional conservatism and board of directors' characteristics. Accounting conservatism produces earnings that reflect bad news faster than good news. Specifically, we analyse whether firms with low CEO influence on board decision making (strong governance structures) are more accounting conservative than firms where the CEO has a high influence on board decision making (weak governance structures). To measure conditional conservatism we use the Basu (1997) and the Ball and Shivakumar (2005) approaches. Both are based on the asymmetric incorporation of news to accounting earnings, that is, on the differential recognition speed of bad news into earnings relative to good news.

The quality of corporate governance is assessed using two aggregate measures that incorporate several characteristics of the board of directors and its monitoring 
Table 7. Measuring accounting conservatism: corporate governance effects controlling for firm economic characteristics. Accruals based analysis. Comparison of the level of accounting conservatism across governance structures:

\begin{tabular}{|c|c|c|}
\hline \multirow[t]{2}{*}{ Intercept } & $\beta_{0}$ & 0.02 \\
\hline & t stat & 2.68 \\
\hline \multirow[t]{2}{*}{$D C F$} & $\beta_{1}$ & 0.00 \\
\hline & $t$ stat & 0.35 \\
\hline \multirow[t]{2}{*}{ Gov6 } & $\beta_{2}$ & 0.00 \\
\hline & $t$ stat & 0.13 \\
\hline \multirow[t]{2}{*}{ DCF Gov6 } & $\beta_{3}$ & 0.14 \\
\hline & t stat & 4.18 \\
\hline \multirow[t]{2}{*}{$C F$} & $\beta_{4}$ & 0.29 \\
\hline & t stat & 6.52 \\
\hline \multirow[t]{2}{*}{ CF Gov6 } & $\beta_{5}$ & 0.04 \\
\hline & $t$ stat & 0.19 \\
\hline \multirow[t]{2}{*}{$D C F C F$} & $\beta_{6}$ & 0.59 \\
\hline & t stat & 4.22 \\
\hline \multirow[t]{2}{*}{ DCF CF Gov6 } & $\beta_{7}$ & 3.46 \\
\hline & t stat & 5.25 \\
\hline $\operatorname{Adj} R^{2}$ & & 0.37 \\
\hline$F$ Value $($ Prob $>F)$ & & $8.61(0.00)$ \\
\hline No. observations & & 193 \\
\hline
\end{tabular}

The sample consists of 193 firm year observations for the period 1997 2002, corresponding to 69 firms. Gov6 is an aggregate measure of corporate governance quality: the residuals from a regression of IndGov6 on a set of variables that measure firm characteristics: (i) size, (ii) market to book ratio, (iii) profitability, (iv) leverage, (v) changes in ownership, and firm and year dummies. The residuals from these regressions are denoted Gov6, and they reflect governance quality orthogonal to these firm characteristics. Higher values of the index are associated to stronger governance. ACCR are total accruals scaled by beginning of period total assets, $C F$ are cash flows from operations divided by beginning of period total assets, $D C F$ is a dummy variable that takes the value of 1 if firm $C F$ are at the lower $5 \%$ of the distribution; 0 otherwise. $\Sigma \alpha_{t}$ represent year dummies (not reported for parsi mony). Reported $t$ statistics are calculated using the Huber White variance covariance matrix, and are robust to the presence of heteroscedasticity and serial correlation (Rogers, 1993).

committees. These measures include the proportion of non-executive directors, the proportion of independent directors, whether the chairman of the board is an executive director, the number of annual board meetings, the existence of an audit committee, the existence of a remuneration/nomination committee, the non-existence of an executive committee and the size of the board. We acknowledge that our measurement is a simplification of the complex construct embodied by corporate governance. Our study focuses on one of its dimensions: certain characteristics of the board of directors. Therefore, our results should be interpreted under this perspective, although, as pointed out below, this does not seem to be a major shortcoming. When building our governance measures we explicitly control for firms' characteristics and contracting environment, so that they are orthogonal to size, growth, profitability, leverage and changes in 
ownership. Controlling for firm characteristics allow us to identify firms that depart from the type of governance that could be considered standard given their characteristics.

Using a sample of Spanish firms for the period 1997 2002, our results indicate that the asymmetric incorporation of news into earnings, and more specifically, the incorporation of bad news into earnings is significantly faster (timelier) in firms with stronger boards. Thus, our evidence is consistent with strong boards using conditional conservatism as a governance mechanism to a greater extent than firms with weaker boards. Furthermore, we show that accounting earnings in firms with weaker boards capture good news faster than the earnings of firms with stronger boards. Put together, these results suggest that weak governance firms report less reliable accounting information than strong governance firms. This result is robust to controlling for differences in the market-to-book ratio, a proxy for differences in growth opportunities and for unconditional conservatism. Differences in the market-to-book ratio could affect the measures of conservatism, so it is important to ensure that the observed differences in conservatism across governance structures are not driven by other factors. Additionally, we also control for firm characteristics that may affect governance choice.

Our findings are consistent with the evidence reported by Beekes et al. (2004) for a UK sample, and Lobo and Zhou (2006), Ahmed and Duellmann (2007) and García Lara et al. (2009) for US samples. These pieces of research use different measures of corporate governance and confirm that accounting conservatism plays an important role in governance. Our results add confidence to the robustness of the association between corporate governance and accounting conservatism, as this relation is shown to exist in a civil-law regime where the demand for conditionally conservative accounting numbers is more reduced given the low impact of litigation risk and the high demand (from financial institutions) for unconditionally (balance-sheet) conservative accounting numbers.

\section{Acknowledgements}

The paper has benefited from presentation at the 2005 AECA Meeting (Oviedo, Spain). We also thank comments and suggestions from two anonymous referees. We acknowledge financial contribution from the Spanish Ministry of Science and Technology (SEJ2005-08644-C02-01/ECON). Juan Manuel García Lara also thanks the financial contribution from SECJ2004-09176-C02-02/ECO.

\section{Notes}

${ }^{1}$ We use the terms interchangeably throughout the paper.

${ }^{2}$ Non executive directors include independent directors and directors representing institutional investors.

${ }^{3}$ Put together, these corporate governance measures determine the power of the CEO. The lower the monitoring exerted by these governance mechanisms, the higher the power of the CEO and 
his ability to entrench himself and expropriate firm resources, by for example, demanding golden parachutes in his contract, or executing a poison pill when facing a takeover threat.

${ }^{4}$ Previous work on audit committee efficiency indicates that the presence of independent direc tors enhances the performance of the audit committee. However, data on audit committee com position are not available.

${ }^{5}$ Following Bertrand and Mullainathan (2001), we use unit weights to create IndGov6 and IndGov8; this is in accordance with the recommendations of Grice and Harris (1998), who show that aggregate measures built using unit weights have better psychometric properties.

${ }^{6}$ Therefore, both indexes are based on internal corporate governance mechanisms, basically related to the power or influence of the CEO over the board. Corporate governance incorporates all the measures and instruments that guarantee investors a return for their investment (Shleifer and Vishny, 1997) and, therefore, a broader set of mechanisms, both internal and external (see, e.g. Gompers et al., 2003). See Shleifer and Vishny (1997), Tirole (2001) and Becht et al. (2003) for more detailed reviews of corporate governance mechanisms.

${ }^{7}$ Accounting earnings are composed of cash flows plus total accruals. Generally, it is assumed that the asymmetric recognition of bad news in earnings is attained via total accruals. Hence, the faster total accruals reflect bad news about the firm, the more conservative earnings will be. ${ }^{8}$ Ryan (2006, footnote 2) states that " $w$ o well known empirical results together imply the biases identified by Dietrich et al. are likely to be fairly small and so biases in returns based measures of asymmetric timeliness are likely to be correspondingly small. First, the low $R^{2}$ s observed in contemporaneous returns earnings regressions suggest that the extent to which earnings causes returns is tiny compared to the extent to which both variables are determined by other, more primitive information. Second, a large literature, only some of which employs the reverse regressions of earnings on returns used to estimate asymmetric timeliness, exists that shows returns typically reflect information on a timelier basis than earnings.'

${ }^{9}$ Ryan (2006) also suggests the approach of Shroff et al. (2004) who examine only large return changes in windows other than earnings announcements. In our case, due to the small number of observations this method is unfeasible.

${ }^{10}$ From 1997 onwards, SpencerStuart publishes an annual report entitled 'Índice Spencer Stuart de Consejos de Administración', that contains the information used in our study.

${ }^{11} \mathrm{We}$ also winsorize one remaining extreme value for the market to book ratio. This does not change the inferences.

${ }^{12}$ Given the high correlation between the existence of an audit committee and a nomination com mittee, in an additional sensitivity check, we delete from the aggregate indexes the nomination committee variable. Our results are not affected if we delete or include this variable.

${ }^{13} \mathrm{All}$ these results are available from the authors upon request.

${ }^{14}$ If we do not include firm or year dummies in equation (1), the market to book ratio and profit ability coefficients become significant.

${ }^{15}$ As an additional test, we analyse if discretionary accruals are used by managers in strong gov ernance firms to make earnings timelier to bad news. We rerun models (2) and (3) using as dependent variable a measure of discretionary accruals and of non discretionary earnings. However, our results are not conclusive. We do not find significant differences in the level of discretionary accruals across strong and weak governance firms. Plus, parametric and non parametric tests of differences of means and medians show that the differences in discretionary accruals across governance structures are not statistically significant. Thus, we cannot conclude that the observed differences in the use of conditional conservatism between strong and weak governance firms are driven by the use of discretionary accruals. Hence, although there might be differences in the use of discretionary accruals across weak and strong governance firms (García Lara et al., 2009; García Osma and Gill de Albornoz, 2007) to induce more con ditional conservatism, the low power of our test does not allow us to detect these differences.

${ }^{16}$ Ball and Shivakumar (2005) define $D C F=1$ if $C F$ is negative. In our sample only seven obser vations present negative cash flows ( $3.6 \%$ of the full sample), this is why we change the 
criterion to define bad news with respect to cash flows. We set bad news as $C F$ that is at the lower $5 \%$ of the distribution. Our inferences do not change if we set the threshold at other levels from $3.6 \%$ to $25 \%$.

\section{References}

Adams, R. B. (2000) What do boards do? Evidence from committee meeting and director compensation, Working Paper, Federal Reserve Bank of New York.

Ahmed, A. S. and Duellman, S. (2007) Accounting conservatism and board of directors' characteristics: an empirical analysis, Journal of Accounting and Economics, 43, pp. 411437.

Aldama Report (2003) Informe de la comisión especial para el fomento de la transparencia y seguridad en los mercados y en las sociedades cotizadas [Report by the Special Commission to Foster Transparency and Security in the Markets and in Listed Companies] (January), Madrid.

Ball, R. and Shivakumar, L. (2005) Earnings quality in UK private firms: comparative loss recognition timeliness, Journal of Accounting and Economics, 39, pp. 83128.

Ball, R., Kothari, S. P. and Robin, A. (2000) The effect of international institutional factors on properties of accounting earnings, Journal of Accounting and Economics, 29, pp. 151.

Basu, S. (1997) The conservatism principle and the asymmetric timeliness of earnings, Journal of Accounting and Economics, 24, pp. 337.

Beaver, W. H. and Ryan, S. G. (2005) Conditional and unconditional conservatism: concepts and modeling, Review of Accounting Studies, 10(2/3), pp. 269309.

Becht, M., Bolton, P. and Röell, A. (2003) Corporate governance and control, in: G. M. Constatinides, M. Harris and R. Stulz (Eds) Handbook of the Economics of Finance, Chapter 1, pp. 1109 (Amsterdam: Elsevier).

Beekes, W., Pope, P. F. and Young, S. (2004) The link between earnings timeliness, earnings conservatism and board composition: evidence from the UK, Corporate Governance, 12(1), pp. 4751.

Berle, A. A. and Means, G. C. (1932) The Modern Corporation and Private Property (New Brunswick, NJ: Transaction).

Bertrand, M. and Mullainathan, S. (2001) Are CEOs rewarded for luck? The ones without principals are, The Quarterly Journal of Economics, 116(3), pp. 901932.

Bhagat, S. and Black, B. (1999) The uncertain relationship between board composition and firm performance, The Business Lawyer, 54(3), pp. 921963.

Booth, J. R. and Deli, D. N. (1996) Factors affecting the number of outside directorships held by CEOs, Journal of Financial Economics, 40(1), pp. 81104.

Bushman, R. M. and Piotroski, J. D. (2006) Financial reporting incentives for conservative accounting: the influence of legal and political institutions, Journal of Accounting and Economics, 42, pp. 107148.

Bushman, R. M., Chen, Q., Engel, E. and Smith, A. (2004) Financial accounting information, organizational complexity and corporate governance systems, Journal of Accounting and Economics, 37, pp. 167201.

Byrd, J. W. and Hickman, K. A. (1992) Do outside directors monitor managers? Evidence from tender offer bids, Journal of Financial Economics, 32, pp. 195222.

Cadbury Report (1992) Report of the Committee on the Financial Aspects of Corporate Governance (London: Gee).

Cahan, S. F. and Zhang, W. (2006) After Enron: auditor conservatism and ex Anderson clients, The Accounting Review, 81(1), pp. 4982.

Chung, R., Firth, M. and Kim, J. B. (2003) Auditor conservatism and reported earnings, Accounting and Business Research, 33(1), pp. 1932.

Conthe Report (2006) Informe del grupo especial de trabajo sobre buen gobierno de las sociedades cotizadas [Report of the Special Working Group on the Good Governance of Listed Companies] (May), Madrid. 
Conyon, M. J. and Peck, S. I. (1998) Board size and corporate performance: evidence from European countries, The European Journal of Finance, 4, pp. 291304.

Core, J. E., Holthausen, R. W. and Larcker, D. F. (1999) Corporate governance, the executive officer compensation, and firm performance, Journal of Financial Economics, 51, pp. 371406.

Cremers, K. J. M. and Nair, V. B. (2005) Governance mechanisms and equity prices, Journal of Finance, 60(6), pp. 28592894.

Davila, A. and Penalva, F. (2006) Governance structure and the weighting of performance measures in CEO compensation, Review of Accounting Studies, 11(4), pp. 463493.

Dechow, P. (1994) Accounting earnings and cash flows as measures of firm performance, Journal of Accounting and Economics, 18, pp. 342.

Dechow, P. M., Huson, M. R. and Sloan, R. G. (1994) The effect of restructuring charges on execu tives' cash compensation, The Accounting Review, 69(1), pp. 138156.

Demsetz, H. and Lehn, K. (1985) The structure of corporate ownership: causes and consequences, The Journal of Political Economy, 93(6), pp. 11551178.

Dietrich, J. R., Muller, K. A. and Riedl, E. J. (2007) Asymmetric timeliness tests of accounting con servatism, Review of Accounting Studies, 12(1), pp. 95124.

Eisenberg, T., Sundgren, S. and Wells, M. T. (1998) Larger board size and decreasing firm value in small firms, Journal of Financial Economics, 48, pp. 3554.

Fama, E. (1980) Agency problems and the theory of the firm, Journal of Political Economy, 88(2), pp. 288307.

Fama, E. and Jensen, M. C. (1983) Separation of ownership and control, Journal of Law and Economics, 26, pp. 301325.

Fama, E. and MacBeth, J. (1973) Risk, return, and equilibrium: empirical tests, Journal of Political Economy, 81, pp. 607636.

Feltham, G. A. and Ohlson, J. A. (1995) Valuation and clean surplus accounting for operating and financial activities, Contemporary Accounting Research, 11(2), pp. 689731.

Francis, J., LaFond, R., Olsson, P. and Schipper, K. (2004) Costs of equity and earnings attributes, The Accounting Review, 79(4), pp. 9671010.

García Lara, J. M. and Mora, A. (2004) Balance sheet versus earnings conservatism in Europe, European Accounting Review, 13, pp. 261292.

García Lara, J. M., García Osma, B. and Mora, A. (2005) The effect of earnings management on the asymmetric timeliness of earnings, Journal of Business Finance and Accounting, 34(3/4), pp. 691726.

García Lara, J. M., García Osma, B. and Penalva, F. (2009) Review of Accounting Studies, forthcoming.

García Osma, B. and Gill de Albornoz Noguer, B. (2007) The effect of the board composition and its monitoring committees on earnings management: evidence from Spain, Corporate Governance: An International Review, 15(6), pp. 14121427.

Gassen, J., Fülbier, R. U. and Sellhorn, T. (2006) International differences in conditional conserva tism: the role of unconditional conservatism and income smoothing, European Accounting Review, 15(4), pp. 527564.

Giner, B. and Rees, W. (2001) On the asymmetric recognition of good and bad news in France, Germany and the United Kingdom, Journal of Business, Finance and Accounting, 28, pp. 12851331.

Givoly, D. and Hayn, C. (2000) The changing time series properties of earnings, cash flows and accruals: has financial reporting become more conservative?, Journal of Accounting and Econ omics, 29, pp. 287320.

Gompers, P., Ishii, J. and Metrick, A. (2003) Corporate governance and equity prices, Quarterly Journal of Economics, 118(1), pp. 107155.

Grice, J. W. and Harris, R. J. (1998) A comparison of regression and loading weights for the compu tation of factor scores, Multivariate Behavioral Research, 33(2), pp. 221247. 
Guay, W. R. and Verrecchia, R. (2006) Discussion of an economic framework for conservative accounting and Bushman and Piotroski (2006), Journal of Accounting and Economics, 42(1/2), pp. 149165.

Hermalin, B. E. and Weisbach, M. S. (1998) Endogenously chosen boards of directors and the monitoring of the CEO, American Economic Review, 88, pp. 96118.

Jensen, M. C. (1993) The modern industrial revolution, exit and the failure of internal control systems, Journal of Finance, 48, pp. 831880.

Jensen, M. C. and Meckling, W. H. (1976) Theory of the firm: managerial behaviour, agency costs and ownership structure, Journal of Financial Economics, 3(4), pp. 305360.

Klein, A. (2002) Audit committee, board of director characteristics, and earnings management, Journal of Accounting and Economics, 33(3), pp. 375400.

LaPorta, R., Lopez de Silanes, F. and Shleifer, A. (1998) Law and finance, Journal of Political Economy, 106(6), pp. 11131155.

LaPorta, R., Lopez de Silanes, F. and Shleifer, A. (1999) Corporate ownership around the world, Journal of Finance, 54(2), pp. 471517.

Ley 44/2002 de 22 de noviembre, de Medidas de Reforma del Sistema Financiero (BOE 281) [Overhaul Measures of the Finance System Act of 22nd of November 2002].

Lobo, G. L. and Zhou, J. (2006) Did conservatism in financial reporting increase after the Sarbanes Oxley Act? Initial evidence, Accounting Horizons, 20(1), pp. 5774.

Olivencia Report (1998) El gobierno de las empresas cotizadas [The Governance of Listed Companies] (February), Madrid.

Pope, P. F. and Walker, M. (2003) Ex ante and ex post accounting conservatism, asset recognition and asymmetric earnings timeliness, Working Paper, Lancaster University and The University of Manchester.

Rangan, S. (1998) Earnings management and the performance of seasoned equity offerings, Journal of Financial Economics, 50, pp. 101122.

Recalde, A. (2003) Los administradores de las sociedades anónimas en un entorno de 'buen gobierno', Revista Valenciana de Economía y Hacienda, 7, pp. 5178.

Rogers, W. (1993) Regression standard errors in clustered samples, Stata Technical Bulletin Reprints, 3, pp. 8394.

Roychowdhury, S. and Watts, R. (2007) Asymmetric timeliness of earnings, market to book and con servatism in financial reporting, Journal of Accounting and Economics, 44(1 2$)$, pp. 231.

Ryan, S. G. (2006) Identifying conditional conservatism, European Accounting Review, 15(4), pp. 511525.

Shleifer, A. and Vishny, R. W. (1986) Large shareholders and corporate control, Journal of Political Economy, 94(3), pp. 461488.

Shleifer, A. and Vishny, R. W. (1997) A survey of corporate governance, Journal of Finance, 52(2), pp. 737783 .

Shroff, P., Venkataraman, R. and Zhang, S. (2004) The conservatism principle and the asymmetric timeliness of earnings: an event based approach, Working Paper, University of Minnesota.

Smith, C. and Watts, R. (1992) The investment opportunity set and corporate financing, dividends, and compensation policies, Journal of Financial Economics, 32, pp. 263292.

Teoh, S. H., Welch, I. and Wong, T. J. (1998a) Earnings management and the under performance of seasoned equity offerings, Journal of Financial Economics, 50(1), pp. 6399.

Teoh, S. H., Welch, I. and Wong, T. J. (1998b) Earnings management and the long run market performance of initial public offerings, Journal of Finance, 53(6), pp. 19351974.

Tirole, J. (2001) Corporate governance, Econometrica, 69(1), pp. 135.

Vafeas, N. (1999) Board meeting frequency and firm performance, Journal of Financial Economics, 53, pp. 113143.

Watts, R. (2003a) Conservatism in accounting Part I: explanations and implications, Accounting Horizons, 17(3), pp. 207221. 
Watts, R. (2003b) Conservatism in accounting Part II: evidence and research opportunities, Accounting Horizons, 17(4), pp. 287301.

Weisbach, M. (1988) Outside directors and CEO turnover, Journal of Financial Economics, 20, pp. 431460.

Xie, B., Davidson, W. N., III and DaDalt, P. J. (2003) Earnings management and corporate governance: the roles of the board and the audit committee, Journal of Corporate Finance, 9(3), pp. 295316.

Yermack, D. (1996) Higher market valuation of companies with a small board of directors, Journal of Financial Economics, 40(2), pp. 187213. 